\section{Hanyang Medical Revi ews}

Hanyang Med Rev 2013;33:190-196

http://dx.doi.org/10.7599/hmr.2013.33.4.190

pISSN 1738-429X eISSN 2234-4446

\section{정상 수면의 생리}

\section{구대림1 - 김주한 ${ }^{2}$}

${ }^{1}$ 서울대학교 의과대학 보라매병원 신경과학교실, ${ }^{2}$ 한양대학교 의과대학 신경과학교실

\title{
The Physiology of Normal Sleep
}

\author{
Dae Lim Koo', Juhan Kim²
}

'Department of Neurology, Seoul National University Boramae Medical Center, Seoul; ${ }^{2}$ Department of Neurology, Hanyang University College of Medicine, Seoul, Korea

Sleep is a highly organized and complicated state that is fundamental to life. We have an absolute need to sleep during about one-third of our lives. There are two types of sleep, non-rapid eye movement (NREM) and rapid eye movement (REM) sleep. NREM sleep is divided into stages 1,2, and 3 which is representing a degree of relative depth in sleep. Each sleep stage shows unique features including some variations in electroencephalographic waves, eye movements, and muscle tone. Although sleep pattern changes are associated with aging, how sleep physiology and sleep patterns change over an individual's life span is not well-defined. Circadian rhythms, which are the daily rhythms in physiology and behavior, regulate the sleep-wake cycle. Comprehensive understanding of normal sleep physiology should be very important to better understand not only the effects of sleep related diseases but also the impacts of pathological sleep on various diseases of other systemic organs. This review aims to enhance knowledge focused on normal sleep physiology and its regulation.

Key Words: Sleep; Physiology; Circadian Rhythm; Neurobiology

\author{
Correspondence to: Dae Lim Koo \\ 우156-707, 서울시 동작구 보라매로 5길 \\ 20 , 서울대학교 의과대학 보라매병원 \\ 신경과 \\ Department of Neurology, Seoul National \\ University Boramae Medical Center, 20 \\ Boramae-ro 5-gil, Dongjak-gu, Seoul \\ 156-707, Korea \\ Tel: $+82-2-870-2473$ \\ Fax: +82-2-831-0714 \\ E-mail: koodaelim@gmail.com \\ Received 23 August 2013 \\ Revised 9 October 2013 \\ Accepted 17 October 2013
}

\section{서 론}

수면은 일반적으로 주위의 감각신호를 감지하지 못하고 그에 대 한 적절한 반응을 보이지 못하는 상태로 정의되지만 실제로 이는 피상적으로 관찰되는 수면의 모습에 불과하다. 수면은 각성 상태 와 다르게 자극에 대한 반응이 떨어진 상태로서 가역적으로 의식 을 되돌릴 수 있다는 점에서 동면이나 혼수 상태와 구별할 수 있다. 능동적 의미의 수면은 낮 시간대에 쌓인 심신의 피로를 회복시키 는 기능뿐만 아니라 수면 중 복잡하고 체계적인 신경신호의 전달과 정을 거쳐 기억력과 인지기능의 향상 등 포괄적 기능을 갖는다[1].

하루 수면 시간은 연령에 따라 달라지는데 일반적으로 어린 나 이에 길고 나이가 들면서 짧아진다. 사람에게 필요한 수면시간은 개인에 따라 차이가 있으며 의도적으로 수면 시간을 조절하기도 한
다. 적정 수면시간의 개인차는 유전적 요인으로 결정되는 것으로 여겨지고 있으며, 만일 주간졸림증의 발생이 수면부족에 의한 것일 경우 주간졸림증 정도의 평가로 개개인의 필요한 수면시간을 예측 할 수 있다[2]. 수면 시간이 불충분하면 주간졸림증과 피로를 쉽게 느끼며, 집중력이 감퇴하고 감정도 날카로워져서 짜증과 화를 내기 쉬워진다. 이러한 상태가 장기간 지속되면 심혈관계 질환이나 정신 질환 등에 걸릴 위험이 높아진다. 따라서 개인별 최적의 수면 시간 을 파악하여 적절한 수면 시간을 유지하는 것이 매우 중요하다.

\section{본 론}

\footnotetext{
1. 수면의 구조

인간의 수면은 기본적으로 비렘(non-rapid eye movement, NREM)
} 


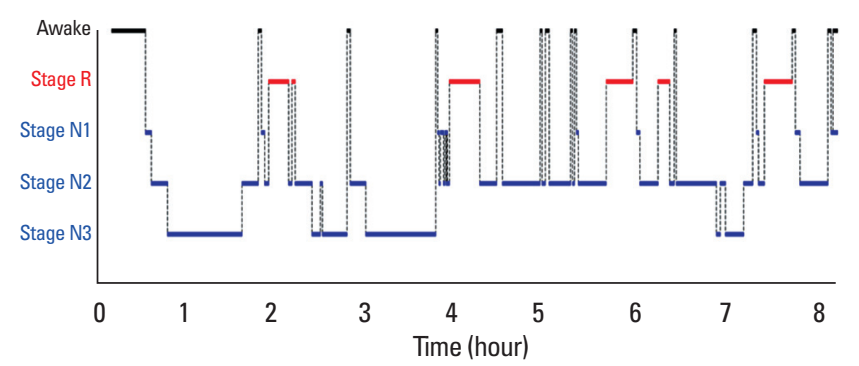

Fig. 1. The hypnogram of a healthy adult represents a normal sleep architecture. There are 4 to 6 sleep cycles during the night. Slow wave sleep (stage N3) is longer early in the sleep period. Rapid eye movement sleep (stage R) increases in frequency and length later during the sleep period. Brief awakenings can be present normally during the sleep period.

수면과 빠른 눈동자 움직임을 보이는 렘(rapid eye movement, REM) 수면의 두 가지로 구분할 수 있다[3]. 비렘수면은 수면의 깊이에 따 라 3가지의 수면단계(N1수면, stage N1; N2수면, stage N2; N3수면, stage N3)로 나눌 수 있고 높은 단계의 더 깊은 수면상태 일수록 각 성 상태로의 전환을 위해서는 더 강한 자극을 필요로 한다(Fig. 1).

수면다원검사(polysomnography)는 수면의 단계와 각성 상태를 평가할 수 있는 표준 검사로서 수면 중 변화되는 다양한 생리적 기 능을 동시에 기록할 수 있는 장점을 가지고 있다. 근전도검사(electromyography)를 통해 근육의 긴장도를 평가할 수 있고 안전위도 검사(electro-oculography)를 통해 안구운동을 확인할 수 있다. 또 한 뇌파검사(electroencephalography)를 통해서 뇌의 활성도를 측 정할 수 있다[2]. 이 외에도 호흡, 맥박, 산소포화도, 사지의 움직임 등을 객관적이고 지속적으로 평가할 수 있어 수면장애가 의심되는 환자의 진단에 매우 유용하다.

2007년 미국수면학회에서 제시한 수면단계에 대한 평가 지침에 따르면 비렘수면에서 관찰되는 뇌파는 몇 가지 특징들을 가지고 있 다[4]. 비렘수면은 상대적으로 수면의 깊이가 낮은 N1수면이나 N2 수면으로 시작해서 고진폭의 델타파를 특징으로 하는 N3수면(서 파수면)으로 진행하게 된다. N1수면에서 관찰되는 소견으로는 느 린 눈동자 움직임, 저진폭의 복합진동수 파형(low amplitude and mixed frequency activity), 두정부 예파(vertex sharp wave)가 있다. $\mathrm{N} 2$ 수면에서는 특징적으로 $\mathrm{K}$ 복합체(K complex)나 $11-16 \mathrm{~Hz}$ 빈도 로 0.5 초 이상 지속되는 수면방추파(sleep spindle)가 관찰된다. N3 수면은 수면뇌파의 30 초 기본단위시간(1 epoch) 동안에 $20 \%$ 이상 에서 0.5-2 Hz 빈도와 $75 \mathrm{uV}$ 이상의 진폭을 보이는 파형이 관찰되 는 단계이다(Fig. 2). N1수면 시 보이는 느린 눈동자 움직임을 제외 하고는 나머지 단계의 비렘수면 동안에는 안구 운동은 잘 관찰되 지 않는다. N1수면은 각성과 수면의 중간 단계로 수면 시작 후 잠에 드는 과정이나 수면 중 잠깐 깨는 경우에 관찰되며 전체 수면 시간 의 2-5\%를 차지하게 된다. 성인에서의 정상적인 N2수면은 총 수면
시간의 45-55\%에서 관찰된다. 서파수면은 주로 수면의 초기 $1 / 3$ 시 기에 집중적으로 나타나며 총 수면시간의 5-15\%를 차지한다.

렘수면의 특징적 소견으로는 양안의 불규칙한 빠른 눈동자 움 직임, 턱근육의 저하된 근긴장도, 저진폭의 복합진동수 뇌파소견이 있다. 이러한 렘수면의 뇌파는 활동적으로 깨어있는 각성 시의 뇌 파소견과 유사하다. 또한 렘수면 동안에는 비렘수면처럼 수면의 깊 이에 따른 단계는 없지만 활동양상에 따라 위상성(phasic)과 긴장 성(tonic)으로 나눌 수 있다. 위상성 렘수면은 교감신경의 영향으로 빠른 눈동자 움직임, 근육의 떨림(muscle twitching), 불규칙한 호 흡 등의 특징적인 소견을 보인다. 반면 긴장성 렘수면은 부교감신경 의 활성도가 증가되어 위상성 렘수면과 비교할 때 상대적으로 빠 른 눈동자 움직임은 관찰되지 않는다.

일반적으로 렘수면은 비렘수면 뒤에 나타나며, 정상인의 8시간 의 수면시간 중 비렘-렘 주기가 3-7회 관찰된다. 첫 렘수면의 지속시 간은 10 분보다 짧을 수도 있는 반면 마지막 렘수면은 60 분 이상 지 속되기도 한다. 렘수면은 밤사이 수면의 후반부에 집중적으로 관 찰되며 전체 수면의 20-25\% 정도 차지한다[3]. 비렘-렘 주기는 수면 의 전반부에는 70-100분 정도이지만 수면의 후반부로 진행하면서 90-120분으로 길어진다[2]. 전체 총수면시간 중 비렘수면이 75-80\% 를 차지하고 렘수면이 $20-25 \%$ 에서 관찰된다. 서파수면인 N3수면 은 수면주기의 첫 $1 / 3$ 분기에 가장 많이 나타나는 반면 렘수면은 마 지막 $1 / 3$ 분기에 주로 관찰된다[3,5]. 이러한 서로 다른 발생분포는 임상적으로 사건수면(parasomnia)이 의심되는 환자의 진단에 유 용하다. 예를 들어 수면의 첫 $1 / 3$ 분기에 사건수면이 발생하는 경우 에는 몽유병(sleepwalking)과 같은 비렘 사건수면을 의심할 수 있 다. 그리고 수면의 후반부에 이상행동이 발생하는 경우에는 렘수 면 동안에 비정상적으로 근긴장도가 소실되지 않는 렘수면 행동장 애를 의심할수 있다.

\section{2. 수면 중 생리학적 변화}

\section{1) 자율신경계}

일반적으로 편안한 각성 상태에 비해 모든 단계의 수면에서 부교 감신경계의 기능이 증가한다. 교감신경계의 기능은 위상성 렘수면 단계에는 증가하고 긴장성 렘수면에서는 오히려 감소한다. 편안한 각성 상태와 비렘수면 동안에는 상대적으로 교감신경계의 기능은 큰 변화를 보이지 않는다. 수면 중 자율신경계 변화를 종합해 볼 때 비렘수면과 긴장성 렘수면 시에는 부교감신경계가 활성화되는 반 면 위상성 렘수면 시에는 교감신경이 우세한 경향을 보인다[6].

\section{2) 체온}

각성 상태와 비교하여 비렘수면 중에는 에너지 소모가 적어지고 더 낮게 설정된 온도에서 체온이 유지된다. 렘수면 동안에는 몸을 떨거나 땀 분비와 같은 체온조절 반응들이 관찰되지 않는다[6,7]. 

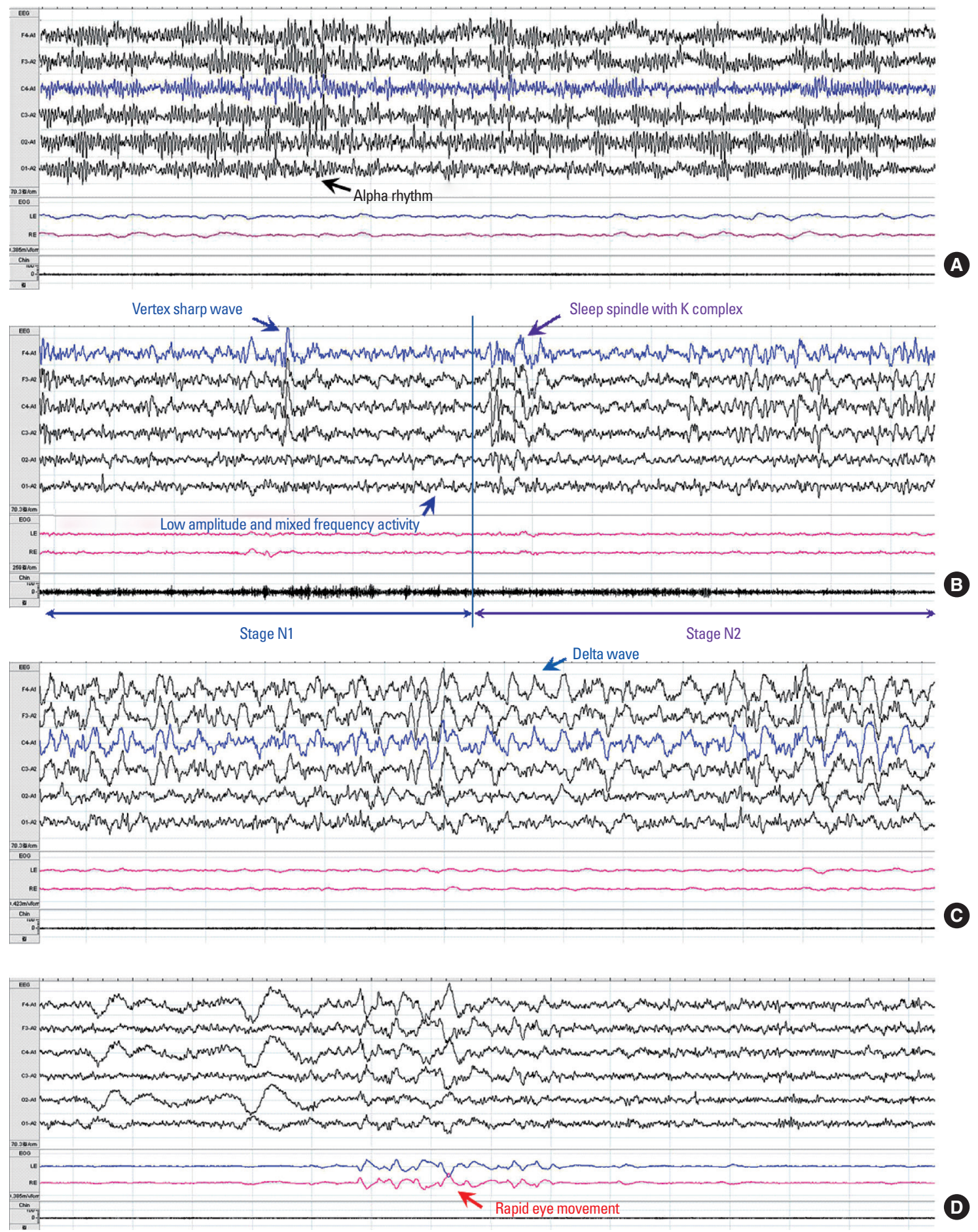

Fig. 2. Typical polysomnographic findings during wake and sleep stages. A. Stage W: Alpha rhytms is the marker for wake stage. B. Stage N1 and N2 sleep: Slow eye movements, low amplitude and mixed frequency activity, vertex sharp waves indicates stage N1 sleep. K complex and sleep spindle are observed during stage N2 sleep. C. Stage N3 sleep: More than $20 \%$ of an epoch consists of slow wave activity during stage N3 sleep. D. Stage R sleep: Rapid eye movements and low chin electromyography (EMG) tone are characteristic features of stage R sleep.

\section{3) 호흡계 및 심혈관계}

비렘수면 시에는 부교감신경계의 긴장도가 증가되고 에너지 소
모는 감소하게 되어 결과적으로 호흡수와 호흡량이 줄어든다. 비렘 수면 동안의 호흡수와 심박수는 규칙적으로 일정하게 유지되어 에 
Table 1. Normal physiologic changes during non-rapid eye movement (NREM) and rapid eye movement (REM) sleep

\begin{tabular}{lcc}
\hline Physiologic parameters & NREM sleep & REM sleep \\
\hline Muscle tone & $\downarrow$ & $\downarrow \downarrow$ \\
Pupil size & $\downarrow$ & $\downarrow$ Tonic phase \\
& Normal & Impasic stage \\
Thermoregulation & $\downarrow$ & $\mid$ Irregular $(\uparrow / \downarrow)$ \\
Heart rate & Regular or stable & Irregular $(\uparrow / \downarrow)$ \\
Blood pressure & $\downarrow$ & Irregular in phasic stage \\
Respiratory rate & $\downarrow$ & $\downarrow$ Phasic stage \\
Respiratory volume & Rare & Frequent \\
Penile erection & & \\
\hline
\end{tabular}

너지 소모를 줄이는 역할을 하게 된다. 반면 렘수면 때에는 호흡 패 턴과 심박동이 매우 불규칙한 특징을 갖는다. 렘수면 기간의 이러 한 불규칙한 심혈관계 기능 변화가 심혈관질환의 고위험군에서 심 근경색을 일으킬 수 있는 위험요소로 작용할 수 있다. 또한 렘수면 동안의 불규칙한 호흡 패턴 변화와상기도의 근긴장도의 변화가 수 면무호흡증을 악화시킬 수도 있다(Table 1).

\section{3. 수면-각성 조절}

수면 및 각성 상태를 유지하는 체계는 수면을 증진시키는 S과정 (sleep homeostatic process, process S)과 각성상태의 유지를 담당 하는 C과정(circadian process, process C)의 상호 작용으로 조절되 는 것으로 여겨지고 있다[8]. S과정은 이전까지의 각성 시간의 양에 의해 결정되는 자려고 하는 힘과 연관된다. 이러한 힘의 증가로 깨 어있는 시간이 길어질수록 수면압력(수면에 대한 필요성)이 증가하 는 것을 설명할 수 있다. 정상인에서 $\mathrm{S}$ 과정의 수면압력은 취침 전 최대치가 되며 적절한 밤 수면 후 사라지게 된다. C과정은 각성상 태를 유지시키는 역할을 하며 하루주기리듬(circadian rhythms)에 의해 조절된다. 즉, $\mathrm{C}$ 과정은 마치 체내의 시계와 같은 역할을 통해 개인의 수면 성향을 결정하는 요인으로 알려져 있다. C과정은 하루 주기리듬에 영향을 미치는 빛과 같은 환경적 요소들의 변화에 의 존하여 일정한 수면-각성 주기를 유지하는데 중요한 역할을 한다. $\mathrm{S}$ 과정의 수면압력은 C과정에 대항하여 낮 시간 동안에 증가되며 밤 수면을 시작하면서 감소한다[8]. 밤 동안의 충분한 수면이 이루어 지면서 S과정이 감소하고 다시 각성주기가 시작된다(Fig. 3). 낮잠을 자게 되면 취침 전 수면압력이 감소하여 잠들기가 어려울 수 있다.

\section{4. 하루주기리듬}

우리 몸의 시신경교차상핵(suprachiasmatic nucleus)에 존재하 는 생체시계(biological clock)는 하루 24.3시간이 조금 넘는 주기로 설정되어 있다. 하지만 우리가 24시간 리듬으로 생활할 수 있는 것 은 체내의 생체시계가 외부요인들에 적절히 동조하기 때문이다. 외 부의 시간에 생체시계를 동조시키는 요인들로는 빛이 가장 중요한

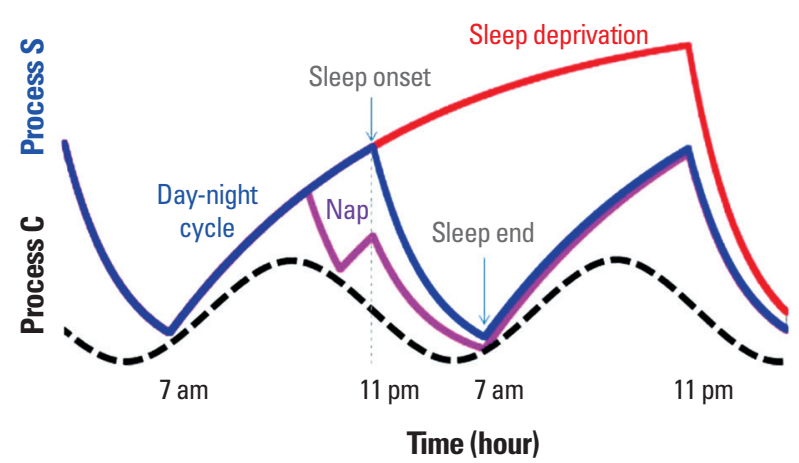

Fig. 3. Two-process model of sleep regulation. Process $\mathrm{S}$ indicates the homeostatic built-up of sleep pressure and Process $C$ represents the circadian rhythm.

역할을 담당하고 있다. 이러한 재조정(reset) 과정에 관여하는 인자 로 낮과 밤, 온도 등의 환경 인자와 일, 가족, 식사 등의 사회적 요인 등이 있다. 이러한 다양한 요인들의 역할로 우리 몸의 생체시계는 정확히 24 시간의 하루 주기에 동조할 수가 있다. 빛 정보가 망막시 상하부로(retinohypothalamic tract)를 거쳐 시신경교차상핵에 전 달되어 생체리듬의 위상 변위를 일으키게 된다. 이 과정에서 빛을 받아들이는 하루 중의 타이밍에 따라 생체리듬이 앞 당겨지기도 하고 뒤로 늦춰지기도 한다[9,10]. 빛이 망막의 신경세포를 자극하 면 시신경교차상핵은 중추신경계의 시간유전자(clock genes)를 재 조정하는데 이 과정에서 심장, 폐, 간, 췌장 등의 말초 조직들의 시 간유전자들을 같이 동기화 시킨다[11-13].

\section{5. 연령에 따른 수면양상의 변화}

사람의 수면 구조는 연령대에 따라 특징적인 차이를 보인다. 유 아기부터 청소년까지의 시기에 수면의 개시, 유지, 총 수면시간, 수 면효율 등에 있어 가장 뚜렷한 변화를 보인다. 일반적으로 나이가 들면서 수면효율은 감소하는 경향을 보인다.

\section{1) 소아의 수면}

신생아는 하루에 16-18시간을 잠을 자지만 한번에 2.5-4시간 이 상 지속해서 수면을 취하기가 어렵다[14,15]. 신생아기와 영아기에 는 비렘수면과 유사한 비활동수면(quiet sleep), 렘수면인 활동수면 (active sleep), 중간단계(intermediate sleep)의 3가지 형태의 수면 패턴을 관찰할 수 있다[16]. 생후 1년간은 어른과 비교하여 2 배에 가까운 시간 동안 수면을 취하게 된다. 또한 잠에 들 때에도 성인과 달리 렘수면으로 시작을 하는 경우가 많다. 생후 첫 1년간은 렘수면 이 전체 수면시간의 $50 \%$ 를 차지하고, 3 세가 되어서야 비로소 성인 의 렘수면 수준인 20-25\%까지 감소하게 된다. 신생아의 비렘-렘수 면 주기는 약 50-60분으로 어른의 90 분과 비교하여 더 짧다. 서파 수면은 태어난 직후에는 관찰되지 않고 생후 2-6개월에 이르러 점 


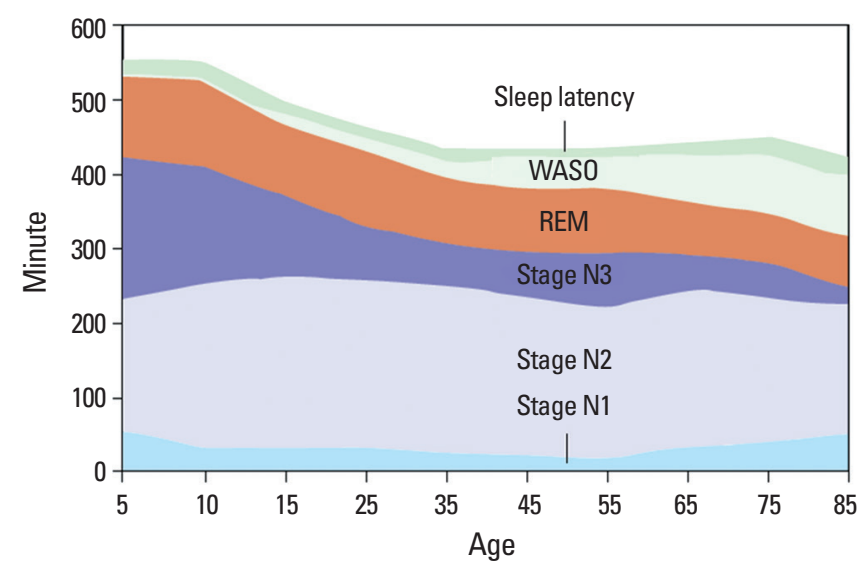

Fig. 4. Sleep and age. WASO, wakefulness after sleep onset; REM, rapid eye movement. Ref. 19 with permission from The Korean Neurological Association.

차 뚜렷하게 나타난다. 수면방추파는 생후 2개월 후부터 관찰되며 성인과 비교하여 훨씬 뚜렷하고 지속시간이 길다. 생후 1년 후부터 수면방추파의 밀도가 점차 감소하여 성인의 형태에 가까워지게 된 다. 생후 6 개월부터는 $\mathrm{K}$ 복합체가 관찰되기 시작한다. 성인에서 보 이는 밤낮 주기를 갖는 수면구조는 생후 3 개월이 지나야 관찰할 수 있다. 생후 6 개월경부터 차츰 밤에 자는 시간이 늘어나고 생후 18 개월이 되면 대부분 낮잠을 한 번만 자게 되고 밤에 10-12시간을 지 속적으로 잘 수 있다. 3-5세에는 대부분의 아이들이 낮잠을 잘 자 지 않기 때문에 오히려 총 수면시간은 11-12시간으로 감소하게 된 다. 학동기에 해당하는 6-12세의 어린이들은 하루 10-11시간동안 수면을 필요로 하고 12-18세의 청소년들도 하루 최소한 9-9.25시간 정도의 수면을 필요로 한다.

\section{2) 노인의 수면}

나이가 들면서 관찰되는 가장 두드러지는 수면구조의 변화는 서 파수면의 양이 점차 감소하는 것이다 $[17,18]$. 노인에서는 잠 들기까 지의 시간이 길어지고 수면 도중 각성 빈도와 깨어있는 시간도 증 가한다. 이 외에도 N1수면과 N2수면이 증가하고 수면의 분절이 늘 어나 수면의 연속성이 깨지게 된다(Fig. 4)[19]. 이러한 노화에 의한 생리적 변화로 오히려 침대에 누워있는 시간은 증가하고 수면효율 도 저하되어 불면증에 더욱 취약하게 된다. 특히 고령에서 흔히 동 반되는 수면무호흡, 근골격계 질환, 심폐질환 등이 수면분절을 더 욱 가속화시키는 역할을 한다.

\section{6. 수면생리와 신경생물학}

수면은 인체 내부의 자극에 대한 반응보다 외부 자극에 대한 반 응이 저하되는 무의식 상태이다. 하지만 이러한 무반응은 가역적으 로 각성 상태로 회복된다는 점에서 다른 무의식 상태와는 뚜렷하
게 구분할 수 있다. 각성 상태에서 수면 상태로 이행되면서 우리 몸 은 점차적으로 시각, 청각 등의 외부 자극에 낮은 반응을 보이게 된 다. 과거에는 수면을 눈을 감는 동작을 통해 외부의 감각 자극을 차 단함으로써 시작되는 수동적인 의미로 생각하였다. 하지만 최근 연 구들에 의하면 수면은 단순히 눈을 감고 움직이지 않는 과정이 아 니라 신체 내에서 생물학적 활동과 대사가 활발하게 이루어지는 복잡한 과정이다[1]. 이러한 수면의 적절한 시기와 질의 결정에 $\mathrm{S}$ 과 정과 C과정이 중요한 역할을 하게 된다.

수면의 생리와 신경생물학을 밝히기 위한 연구는 크게 뇌파 연 구와 뇌영상 연구로 나눌 수 있다. 첫째, 수면 중 뇌파분석 연구에 따르면 비렘수면 동안에는 시상과 대뇌 사이에서 발생하는 3 가지 형태의 진동성 파형들을 관찰할 수 있다. 1) N2수면의 지표인 수면 방추파는 시상의 그물핵(reticular nucleus)에서 과다분극된 gamma-amino butyric acid (GABA) 신경원의 돌발파(bursts)로 형성 되며 이 자극은 시상에서 피질로의 신호를 억제하는 역할을 한다. 2) 시상의 그물핵 신경원의 과다분극이 진행되면서 시상과 피질의 피라미드로(pyramidal tract) 신경간의 동기화에 의하여 델타진동 (delta oscillation)이 형성된다. 3) 마지막으로 피질의 신경회로에서 과다분극과 탈분극의 주기적 반복으로 형성되는 느린 주파수의 피 질진동(cortical oscillation)을 관찰할 수 있다. 비렘수면 시에 관찰 할 수 있는 이상의 3 가지 진동파형들은 기억력을 강화시키고 시냅 스간 신경 회로를 최적화 시키는 역할을 한다[20]. 둘째, 뇌페트 (brain positron emission tomography) 검사 등의 뇌영상기법을 이 용한 수면의 단계별 혈류 변화에 관한 연구에 따르면 비렘수면 기 간에는 뇌의 대사요구량이 감소되어 뇌 전체에서 혈류가 감소하는 소견을 보였다. 반면 렘수면 동안에는 시상, 일차시각영역, 운동영 역, 감각영역의 피질에서 혈류가 증가되었다. 특히 일차시각영역에 서의 혈류 증가는 렘수면 동안의 생생한 꿈과 연관이 있다는 연구 보고가 있다[21,22].

렘수면은 중뇌 및 교뇌에 위치한 렘작동신경원(REM-on neurons)에 의한 아세틸콜린(acetylcholine) 분비에 의해 시작된다. 대 뇌다리교뇌뒤판(pedunculopontine tegmentum)과 가등쪽뒤판 (laterodorsal tegmentum)에서 분비된 아세틸콜린이 시상을 거쳐 대뇌의 비동기화를 가져온다. 피질의 비동기화는 뇌파에서는 렘수 면을 시사하는 저진폭복합진동수(low voltage mixed frequency) 파형이나 톱날파형(sawtooth waves)으로 관찰된다. 렘수면의 양은 항콜린제를 사용하면 감소하고 콜린성 약물을 복용하면 증가한다. 렘비작동신경원(REM-off neurons)은 청색반점(locus ceruleus)과 솔기핵(raphe nucleus)에 존재하며 노르에피네프린(norepinephrine), 세로토닌(serotonin), 히스타민(histamine) 등의 분비를 통해 렘작동신경원을 비활성화시켜 렘수면을 종료시킨다. 노르에피네 프린이나 세로토닌의 농도를 증가시키는 항우울제를 복용하면 렘 수면이 억제된다[23,24]. 
Awake

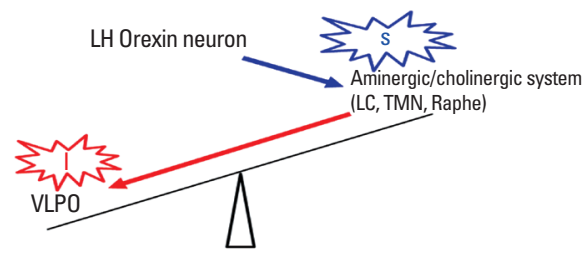

Sleep

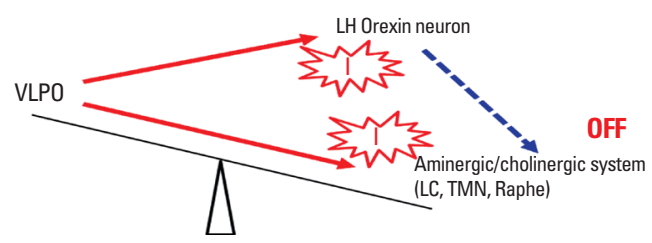

Fig. 5. Sleep-wake regulation: 'flip-flop' switch model. I, inhibition; $\mathrm{S}$, stabilization; VLPO, ventrolateral preoptic nucleus; TMN, tuberomammillary nucleus; LH, lateral hypothalamus; Raphe, raphe nuclei; LC, Locus coeruleus.

아데노신(adenosine)은 수면의 항상성에 관여하는 인자로서 각 성상태에서 비렘수면상태로의 전환에 관여한다 $[6,9,25,26]$. 시상 하부에 위치하는 배가쪽시각교차앞핵(ventrolateral preoptic nucleus)은 수면을 시작하게 하는 스위치 역할을 하는 것으로 알려져 있다. 활성화된 배가쪽시각교차앞핵 신경은 GABA와 갈라닌(galanin)과 같은 억제성 신경전달물질을 분비하여 각성을 담당하는 영역들을 억제하여 수면을 유발시킨다[27]. 각성을 담당하는 뇌구 조물로는 히스타민(histamine)을 분비하는 결절유두핵(tuberomammillary nucleus), 히포크레틴(hypocretin)을 분비하는 천장주 위영역(perifornical area), 세로토닌 분비를 담당하는 솔기핵, 아세 틸콜린을 분비하는 가등쪽뒤판/대뇌다리교뇌뒤판, 도파민을 분비 하는 배쪽뒤판영역(ventral tegmental area), 노르아드레날린(noradrenaline)을 분비하는 청색반점 등이 있다. 결절유두핵의 억제는 뇌간과 시상 및 대뇌 사이간의 상호작용의 기능을 저하시켜서 잠 에 들게하는 가장 중요한 과정이다. 또한 결절유두핵의 억제 신호 는 바로 아래쪽에 위치한 교뇌그물계(pontine reticular system)에 작용하여 상행성의 아세틸콜린 전달을 차단한다[23].

반면 각성 상태 동안에는 아세틸콜린과 아민의 분비를 담당하는 신경계가 반대로 배가쪽시각교차앞핵을 억제하게된다. 배가쪽시 각교차앞핵과 모노아민 신경의 상호 억제 방향에 따라 수면과 각 성 상태로 신속하게 상호 전환되며, 이러한 작동 원리가 마치 시소 와 유사하여 flip-flop 스위치 모형으로 알려져 있다(Fig. 5)[24]. 가 쪽 시상하부의 신경에서 분비되는 히포크레틴/오렉신(orexin)은 이 러한 flip-flop 스위치를 안정화 시키는 역할을 한다. 히포크레틴의 농도가 비정상적으로 낮아서 갑자기 잠에 빠지는 질환이 바로 기면 증이다[28]. 수면의 단계 중 비렘수면을 형성하는데 배가쪽시각교 차앞핵이 필수적인 역할을 한다. 반면 렘수면은 콜린성 신경과 아 민성 신경의 상호작용에 의해 형성된다. 렘수면 시 가등쪽뒤판/대 뇌다리교뇌뒤판에서 분비된 아세틸콜린이 시상을 흥분시켜 피질
의 비동기화를 일으킨다[29]. 또한 아세틸콜린은 아래쪽의 연수에 작용하여 글라이신(glycine)을 분비시킨다. 분비된 글라이신은 앞 뿔세포(anterior horn cell)의 과다분극을 통해 운동신경계를 억제 하여 렘수면 동안 무긴장증을 유발하는 것이다[30].

\section{결 론}

수면은 각성의 반대 개념으로 단순히 수동적으로 쉬는 것이 아 니라 생존에 필요한 기능을 체계적으로 수행하는 능동적인 과정이 다. 실제로 수면 동안에 다양한 신경들의 복잡하고 유기적인 상호 작용이 이루어진다. 적절한 수면이 이루어지지 않으면 다음 날 주 간에 졸리고 집중력과 기억력이 저하된다. 이러한 불량한 수면이 지속되면 심장, 폐, 근골격계 등에 문제가 발생하여 신체 건강을 해 치게 된다. 수면 중에 일어나는 다양한 생체신호들의 변화를 객관 적으로 평가할 수 있는 수면다원검사는 수면상태의 적절성을 평가 할 수 있을 뿐만 아니라 정상수면을 방해하는 동반된 수면장애가 있는지도 확인할 수 있는 매우 유용한 검사이다. 최근에는 수면과 수면장애가 점차 중요시되고 있으며 수면의 생리적 측면, 생화학적 분야, 유전학적 측면 등 다양한 방면에서의 연구들이 활발히 진행 되고 있다. 이러한 수면에 대한 폭 넓은 이해는 단독 수면질환은 물 론 동반하는 다른 신체 질환들의 진단과 치료 방향의 결정에 큰 도 움이 될 것이다.

\section{REFERENCES}

1. Siegel JM. Clues to the functions of mammalian sleep. Nature 2005;437: 1264-71.

2. Sinton CM, McCarley RW. Neurophysiological mechanisms of sleep and wakefulness: a question of balance. Semin Neurol 2004;24:211-23.

3. Carskadon MA, Dement WC. Normal human sleep: An overview. In Kryger MH, Roth T, Dement WC, eds. Principles and practice of sleep medicine. 5th ed. St. Louis: Elsevier Health Sciences; 2011:16-26.

4. Iber C, Ancoli-Israel S, Chesson A, Quan SF. The AASM manual for the scoring of sleep and associated events: rules, terminology and technical specifications, 1st ed. Westchester, IL: American Academy of Sleep Medicine, 2007.

5. Markov D, Jaffe F, Doghramji K. Update on parasomnias: a review for psychiatric practice. Psychiatry (Edgmont) 2006;3:69-76.

6. Roth T, Roehrs T. Sleep organization and regulation. Neurology 2000;54: S2-7.

7. Kräuchi K, de Boer T. Body temperature, sleep, and hibernation. In Kryger $\mathrm{MH}$, Roth T, Dement WC, eds. Principles and practice of sleep medicine. 5th ed. St. Louis: Elsevier Health Sciences; 2011:323-34.

8. Achermann P, Borbély AA. Sleep homeostasis and models of sleep regulation. In Kryger MH, Roth T, Dement WC, eds. Principles and practice of sleep medicine. 5th ed. St. Louis: Elsevier Health Sciences; 2011:43144.

9. Pace-Schott EF, Hobson JA. The neurobiology of sleep: genetics, cellular physiology and subcortical networks. Nat Rev Neurosci 2002;3:591-605. 10. Brzezinski A. Melatonin in humans. N Engl J Med 1997;336:186-95. 
11. Young ME, Bray MS. Potential role for peripheral circadian clock dyssynchrony in the pathogenesis of cardiovascular dysfunction. Sleep Med 2007;8:656-67.

12. Dibner C, Schibler U, Albrecht U. The mammalian circadian timing system: organization and coordination of central and peripheral clocks. Annu Rev Physiol 2010;72:517-49.

13. Berson DM, Dunn FA, Takao M. Phototransduction by retinal ganglion cells that set the circadian clock. Science 2002;295:1070-3.

14. Roffwarg HP, Muzio JN, Dement WC. Ontogenetic development of the human sleep-dream cycle. Science 1966;152:604-19.

15. Adair RH, Bauchner H. Sleep problems in childhood. Curr Probl Pediatr 1993;23:147-70; discussion 142.

16. Davis KF, Parker KP, Montgomery GL. Sleep in infants and young children: Part one: normal sleep. J Pediatr Health Care 2004;18:65-71.

17. Bliwise DL. Normal aging. In Kryger MH, Roth T, Dement WC, eds. Principles and practice of sleep medicine. 5th ed. St. Louis: Elsevier Health Sciences; 2011:27-41.

18. Roth T. Characteristics and determinants of normal sleep. J Clin Psychiatry 2004;65 Suppl 16:8-11.

19. The Korean Neurological Association. Textbook of Neurology. 2nd ed. Seoul: Bummoon Education; 2012:413.

20. Chokroverty S. Physiologic changes in sleep. In Chokroverty S, ed. Sleep Disorders Medicine. Boston: Butterworth-Heinemann; 1999:95-126.

21. Desseilles M, Dang-Vu T, Schabus M, Sterpenich V, Maquet P, Schwartz S. Neuroimaging insights into the pathophysiology of sleep disorders. Sleep
2008;31:777-94.

22. Braun AR, Balkin TJ, Wesenten NJ, Carson RE, Varga M, Baldwin P, et al. Regional cerebral blood flow throughout the sleep-wake cycle. An H2(15)O PET study. Brain 1997;120 ( Pt 7):1173-97.

23. Espana RA, Scammell TE. Sleep neurobiology for the clinician. Sleep 2004;27:811-20.

24. Saper CB, Scammell TE, Lu J. Hypothalamic regulation of sleep and circadian rhythms. Nature 2005;437:1257-63.

25. Borbély AA, Achermann P. Sleep homeostasis and models of sleep regulation. J Biol Rhythms 1999;14:557-68.

26. Mignot E, Taheri S, Nishino S. Sleeping with the hypothalamus: emerging therapeutic targets for sleep disorders. Nat Neurosci 2002;5 Suppl: 1071-5.

27. Saper CB, Cano G, Scammell TE. Homeostatic, circadian, and emotional regulation of sleep. J Comp Neurol 2005;493:92-8.

28. Siegel JM, Moore R, Thannickal T, Nienhuis R. A brief history of hypocretin/orexin and narcolepsy. Neuropsychopharmacology 2001;25:S1420.

29. Boissard R, Gervasoni D, Schmidt MH, Barbagli B, Fort P, Luppi PH. The rat ponto-medullary network responsible for paradoxical sleep onset and maintenance: a combined microinjection and functional neuroanatomical study. Eur J Neurosci 2002;16:1959-73.

30. Curtis DR, Hosli L, Johnston GA, Johnston IH. The hyperpolarization of spinal motoneurones by glycine and related amino acids. Exp Brain Res 1968;5:235-58. 